\title{
GLBTQ content in comics/graphic novels for teens
}

\author{
Devon Greyson, MLIS \\ Centre for Health Services and Policy Research, Vancouver, Canada \\ devon@chspr.ubc.ca
}

\begin{abstract}
:
Purpose - This paper aims to provide an historical perspective and current guidance for youth librarians collecting graphic novels for teens.

Design/methodology/approach - The paper provides a brief review of the historical issues involved with censorship/intellectual freedom and comics and of current teen-oriented graphic novels with gay, lesbian, bisexual, transgender, queer, and questioning of sexual orientation (GLBTQ) content in Canada and the USA. It also provides a context for negotiating intellectual freedom and collection management policy issues, and suggestions for targeted acquisitions of teen graphic novels with GLTBQ content.

Findings - The paper provides a brief overview of US and Canadian censorship of comics, including how this legacy affects today's market. It recognizes the difficulty of obtaining information and recommendations for teen-appropriate graphic novels containing GLBTQ content, and makes suggestions for core collection items.

Research limitations/implications - Only English sources from the USA and Canada are reviewed. Francophone Canadian literature is relevant but outside of the scope of this paper.

Practical implications - The paper is a useful source of information for the librarian looking for collection development suggestions, and/or for the librarian dealing with or preparing against intellectual freedom challenges to graphic novels or GLBTQ material for teens.

Originality/value - This paper furthers discussion of censorship of graphic novels and of GLBTQ material, and provides concrete suggestions to librarians developing a teen graphic novel collection. The issue is timely, as the graphic novel industry is booming and the ALA has documented an increasing number of challenges to graphic novels in libraries. Few previous papers on graphic novels or comics have included Canadian content, although the CanadaAmerican library worlds, publishing industries and legal codes are historically and currently intertwined.
\end{abstract}

Keywords Censorship, Homosexuals, Comics, Young adults, Canada, United States of America

Paper type General review

Author's final copy of article published in:

Collection Building

26/4 (2007) 130-134

$q$ Emerald Group Publishing Limited [ISSN 0160-4953]

[DOI 10.1108/01604950710831942]

When discrepancies exist, the authoritative copy is that published in Collection Building.

The current issue and full text archive of this journal is available at:

http://www.emeraldinsight.com/0160-4953.htm 
Introduction

Graphic novel collections in libraries are increasing in popularity, as the medium gains respectability and popularity as a form of art and literature, and as libraries seek ways to connect with teen audiences. A 2005 article in $C \& R L$ News asserted that graphic novels and comic books are "becoming two of the most pervasive and influential media forms of popular culture" (Bussert, 2005). Market forces seem to agree, as the comic sector is now "one of the fastest growing sectors of the publishing industry, selling \$250 million last year, according to market research firm ICV2 Publishing" (Associated Press, 2006). That is triple the \$75 million in sales just five years ago in 2001.

If your public library does not collect graphic novels, it may be just a matter of time before you begin. Young adults are seen as prime audience for graphic novels, but the guidance for selecting teen graphic materials is sparse compared with that for books. This lack of guidance is especially striking when examined in light of a subject area potentially tricky for youth librarians to navigate: that of gay, lesbian, bisexual, transgender, queer, and questioning of sexual orientation (GLBTQ) issues. While teen librarians are increasingly selecting and promoting resources that address GLBTQ issues for young adults, including comics in this process is not simple.

Visual media such as comics can easily attract attention of community censors. Because of the pervasive (albeit mistaken) idea that comics are a children's genre, comic books with more mature themes are potential fertile ground for material challenges in our libraries (Lavin, 2001a). Indeed, cases of censorship of comics are on the rise (Williams, 1994), with the ALA documenting at least 14 challenges over the past two to three years (Twiddy, 2006), and a graphic novel turning up on the CLA's 2006 "Tracking Challenged Resources in Canadian Libraries" survey as well.

American comic books developed in the 1930s, with alleges superheroes and talking animals as primary content. Around the Second World War, more adult genres, including crime, horror and romance, became popular. Senate Committee hearings, based on Dr Frederic Wertham's crusade to blame comics for juvenile delinquency and sexual deviance, led to the comics industry creating a voluntary "Comics Code" of morality. The Comics Code Authority was a conservative force influencing mainstream comics through the 1980s, and implicitly prohibited any positive portrayal of GLBTQ characters.

The Canadian comics market has generally been dominated by US publishers. While parallel social concerns arose in the 1940s, the Canadian solution was to pass legislation (the "Fulton Bill") within the obscenity provisions of the Criminal Code, prohibiting crime comics and other obscenity. Like the Comics Code, the Fulton Bill still exists, although it is not frequently called into action. Unlike the Comics Code, the Fulton Bill carries the weight of law enforcement, which has recently been applied specifically to target GLBTQ materials passing through customs into the country.

This article will look at the development of GLBTQ comics in this climate of censorship. It will offer a brief review of GLBTQ comics, discuss challenges facing teen librarians attempting to provide appropriate reading materials and guidance for youth, and offer collection recommendations.

\section{GLBTQ content in comics}

\section{Comic strips}

Comic strips have a broader audience than graphic novels, being originally distributed via newspapers and magazines (Applegate, 1994). The majority of comic strips also tend to be modeled on regular daily life, and with that has come mirroring the issues people are dealing with, including sexual orientation.

Perhaps the first gay and lesbian cartoon characters to grace the funny pages both appeared in Milt Caniff's 1930s Terry and the Pirates (Applegate, 1994). Neither of these characters was obviously "out," but both were clearly acting in a way we might now consider to be gay or queer. Despite occasional sightings of such characters likely intended to read as gay or lesbian, most newspaper strips remained bound by the Comics Code Authority, which kept GLBTQ representation limited to offensive stereotypes. Not until the 1970s, when the Code's regulatory stronghold loosened in the face of independent cartoons and social movements including gay and women's liberation, was there space for more realistic and sensitive portrayals of GLBTQ characters on the funny pages (Theophano, 2002). 
More recently, a few mainstream newspaper comics have grappled with the issue of gay characters in a more explicit way. Garry Trudeau's Doonesbury is commonly thought to have showed the first out gay character in a mainstream comic strip when, in 1977, character Andy Lippencott came out as gay. Andy later died with AIDS, but another character, Mark Slackmeyer, began his coming out process in 1993 (Applegate, 1994).

A notable Canadian example of a newspaper comic strip character's coming out is that of Lawrence Poirier in Canadian cartoonist Lynn Johnston's For Better or for Worse. Lawrence, childhood buddy of the eldest child in the family around whom the strip revolves, came out in a series of strips that ran in spring 1993 (Theophano, 2002). The repercussions of this courageous sequence were highly publicized and can still be read about on Johnston's web site, along with Johnston's own explanation for why she made Lawrence gay.

While comic strips reach a slightly different (and much broader) audience than comic books and graphic novels, the genres are related enough for progress toward inclusion of GLBTQ characters in one genre to influence the other. And since For Better or for Worse is such a long running syndicated strip, it can be noted that the response to a subsequent sequence regarding Lawrence's sexual orientation in 1997 was much more muted, evoking far less protest just a few years after than the original coming out story (Editor \& Publisher, 1997).

\section{Comic books and graphic novels}

The Comics Code did not entirely prevent gay comics from being created and circulated. Comic artists, rather, were faced with the choice either to be cryptic and leave questions of sexual orientation vague, or to be explicit and find their comics relegated to the gay "comix" (spelling commonly used to refer to independent or underground comics) publishers. In her GLBTQ Encyclopaedia entry on "Comics," Theophano (2002) writes:

Gay and lesbian readers continued to speculate about the real relationship between Batman and Robin and between Wonder Woman and her Amazons, but the creators and distributors of these strips were prohibited from developing those relationships.

While The Advocate and other emerging gay magazines did run gay comics, mainstream strips rendered GLBTQ role models for young people reading newspapers and comics virtually invisible.

The first documented openly gay male comics date back at least to the 1940s, when Tom Finland was creating sexually explicit adult gay comics for his community. The earliest documented lesbian comic book was Mary Wing's Come out Comix, decades later in 1972 (Theophano, 2002). The feminist Wimmens Comix handled some degree of lesbian and bisexual content from the start (Robbins, 1999), and was the vehicle for Roberta Gregory to come out as the first publicly lesbian cartoonist in 1974. Soon Gregory was publishing her own lesbian comic book, Dynanite Damsels.

Cathartic Comics, created by Rupert Kinnard in 1977, made history as the first published out, queer, Black comic. By the late 1970s, the underground gay and lesbian press was in full swing, although the bulk of the comics remained by and for men through the 1970s and 1980s. Gay Comics (originally Gay Comix), an annual volume first published in 1980, is considered to be a landmark publication due to its long ( 25 year) run and wide appeal, crossing over into mainstream readership (Theophano, 2002).

In mainstream comic books, especially those oriented toward young people, change was a bit later in coming. But the social movements were unstoppable, and it was only a matter of time before DC Comics briefly introduced an effeminate Hispanic gay man, unflatteringly named Extraño. In the early 1970s, DC Comics experimented with edgier themes in romance comics - an attempt to keep the genre viable - and introduced the first lesbian-seeming characters, although the word "lesbian" was never used (Robbins, 1999). Comics on the edge of mainstream publication lists introduced gay characters in the later 1980s and 1990s, including Fantagraphics' Love and Rockets by Gilbert and Jaime Hernandez, and Neil Gaiman's Sandman comics, published by DC's edgier Vertigo imprint.

DC has been a leader of the mainstream publishing pack in this regard, even introducing transsexual themes in a couple of titles. And while in 1980, "gay people simply did not exist in the "Marvel Universe"" (Theophano, 2002), by 1992 a Canadian Marvel Comics hero, Alpha Flight's Northstar, came out. DC and Marvel are by far the biggest players in the comic industry as far as market share: in 2005, Marvel produced 44 percent of the comics purchased in the USA,

and DC was not far behind, producing 37.5 percent. For comparison, the third place comic company, Dark Horse Comics, made 3.5 percent (Newsarama.com, 2005). While mainstream comics publishers have been introducing GLBTQ characters, the GLBTQ independent publishing world has been increasing in financial stability as well as accessibility to the general public. There are numerous professional GLBTQ cartoonists these days, many of whom 
have volumes of their work published as graphic novels. Some of the big names in this genre are Alison Bechdel (Dykes to Watch out For), Diana DiMassa (Hothead Paisan: Homicidal Lesbian Terrorist), Howard Cruise (founder of Gay Comics and author of acclaimed DC published graphic novel Stuck Rubber Baby), and Gerard Donelan (frequent contributor to Frontiers magazine and the Meatmen gay comics anthologies). As may be obvious by the titles, some of these comics may not be appropriate for young readers for reasons of sexual or violent explicitness.

\section{The current situation}

Today's market - GLBTQ representation in teen comics?

Many GLBTQ comics are independently or self-published, and, therefore, have no big advertising or distribution arrangements. However, a few are beginning to be published by major publishers. Marvel's $X$-Men is a comic that has historically spoken to GLBTQ audience. Queer teens frequently relate to the imaginary world of the X-Men, in which mutant super-powered teens are treated like outcasts, with storylines including heroes "coming out" about their special gifts (Giltz, 2003). In addition to Alpha Flight's Northstar coming out as gay in the comic, other characters within the group are the subject of speculation (Provenzano, n.d.). The recent X-Men movies have featured known gay and gay-friendly actors for the sometimes gender-bending main roles. Marvel Comics' new title The Young Avengers, created by gay writer Allan Heinberg, may also feature a gay superhero couple (Advocate, 2005).

DC Comics' Green Lantern has grappled with gay issues in recent years as well. Sidekick Terry came out as gay in 2001, garnering the comic critical acclaim from the Gay and Lesbian Alliance Against Defamation (Dobnik, 2002). Cartoonist Judd Winick, who created Terry's character at the suggestion of editor Bob Schreck, is best known for his earlier graphic novel, Pedro and Me, about his gay roommate who died with AIDS. According to Winick (cited in Dobnik, 2002):

$$
\text { [. . . ] it would be great for young people to see that the Green Lantern doesn't care that Terry is gay. He's a person. }
$$

In a later issue, Terry gets assaulted by gay-bashers, and is saved when the Green Lantern, suits up and confronts the homophobic attackers. Green Lantern has challenged the Comics Code from its 1960s inception, dealing with social problems such as racism and sexism, but skirting topics such as drugs, which were explicitly forbidden by the code (Nyberg, 1998). In keeping with its reputation as a socially relevant comic, the gay Green Lantern storyline represented a bold step by a very popular youth-focused comic, especially considering the parent company of DC these days is the famously "family friendly" AOL. According to Shreck and Winnick, they have received heartening positive reader feedback to the development (Ferber, 2002). Green Lantern also occasionally features the lesbian pair Lee and Li as supporting characters (Provenzano, n.d.).

Also by DC, on the Vertigo imprint, are several other comics with GLBTQ characters or themes. The Authority has two gay characters who have been shown kissing. Out gay writer and artist Phil Jimenez is one of the creators of The Invisibles, which features a diverse cast of queer characters, including transgender witches. Jimenez also wrote the new Wonder Woman series (2000), which perhaps finally settles the question about whether the Amazon is a lesbian. According to Jimenez, "If we can do mainstream work and touch people that way, I want to take advantage of that" (PlanetOut.com, 2005).

\section{What's a youth librarian to do?}

As with other materials, your library's collection policies will determine what comics are appropriate for the teen collection. Literary/artistic quality, popular demand, and representation of diversity all play a role in selection. The classifications "young adult" and "teen" may have varying definitions among libraries, publishers, and distributors: what is age appropriate for a 17 year old is quite different from what may be suitable for a ten-year-old reader. Lavin's (2001b) web site, Comic Books for Young Adults warns:

With the exception of clean-cut Archie comics, all major comics publishers issue some titles which are unsuitable for younger readers.

Lavin (2001b) goes on to mention the double standard for text and graphic media in young adult collection development, namely:

Because comics are a visual medium, explicit material tends to be more overt.

This double standard for written and visual media is really the crux of the matter. In creating or revising a graphic novel collection policy, it can be a struggle to adhere to ideals of intellectual freedom while at the same time avoiding charges of distributing pornography to minors. 
If you have a graphic novel collection, take a close look at how it represents your community. Are there comics with positive representations of GLBTQ youth? Are your graphic novels integrated into your thematic booklists? Few GLBTQ booklists for teens from public libraries include graphic novels alongside other materials. One example of a booklist that does a good job of this integration is that of the Berkley Public Library in California (Berkeley Public Library, 2005).

If you wish to improve the diversity of your collection, a primary challenge is identifying appropriate comics. The Japanese manga graphic novels self label with a rating system: Y (or youth) for age seven and up, T for teen-rated, and OT (older teen) for age 16 and up (Green, 2003). However, most North American comics find themselves choosing between the ridiculously outdated Comics Code seal of approval for children, self-labeling as "For Mature Readers" or doing nothing. Is it any surprise that many do not print a rating label at all?

The fact that most comics in North America have no labels at all guiding readers to the type of content makes it difficult to select materials for a youth collection, especially in a controversial area such as GLBTQ content for teens. As it is

simply not possible to personally read every item considered for collection development, we rely heavily on reviews and distributors. But few GLBTQ comics are carried by mainstream distributors, such as Diamond Comics Distributor, the largest provider of comics to American libraries. So where might a youth librarian find teen comics with GLBTQ content?

Industry resources within the library or comics world are of varying degrees of help. Voice of Youth Advocates runs a graphic novel review column three times a year, Publishers Weekly runs a "Comics" column four times a year, and Library Journal, School Library Journal, Booklist, among other review periodicals, occasionally review comics (Raiteri, 2002). YALSA's annual booklists do now contain graphic novels, and the group is starting a graphic novel recommendation webpage (Young Adult Library Services Association, n.d.).

There are a growing number of books on graphic novels or teen collections and services, which can act as aids in your own collection development. But few of these index or highlight GLBTQ content or issues as a thematic category. Comic reviewing websites are numerous, but most are not teen focused and do not evaluate a graphic novel's age appropriateness for young readers. A notable exception to this is No Flying No Tights, Robin Brenner's web site created specifically to review and recommend comics and graphic novels for teens, which breaks down the contents into target age groups as well as grouping them by theme (Brenner, 2005). Unfortunately, Brenner's web site neither groups nor indexes GLBTQ themes.

Colleagues, reviews, word of mouth, and your local comic store and/or GLBTQ bookstore are perhaps the best tools for staying abreast of new publications. Most local stores would love to have your library's business if institutional policies allow direct purchasing. Such independent vendors may be happy to pull aside appropriate materials for your review, and can be in touch with your local community needs and interests.

Where does this leave us? Faced with a legacy of censorship, we live under outdated laws and codes of ethics. While comics may have faded from the public eye since the 1950s, the same arguments made by Wertham and Fulton then are echoed by censors of youth media today. With the profile of comics growing once more, we must be prepared against possible future challenges and attacks - fortunately, guidance and assistance can be found from organizations such as the National Coalition Against Censorship, the American Library Association, and the Comic Book Legal Defense Fund (National Coalition Against Censorship, American Library Association and Comic Book Legal Defense Fund, 2006).

\section{Collection recommendations}

Your library's teen graphic novel collection will be governed by its own particular selection policies, and rightfully so. It is our job as librarians to manage collections that meet the needs of our individual communities. This caveat is offered, as not all of the following recommendations will seem appropriate to all libraries. That said, what follows is a brief list of some of the most highly recommended contemporary comic and graphic novel titles to consider for adding GLBTQ content to your collection. There is by no means an exhaustive list, but is meant to highlight by publisher some of the best comics with GLBTQ content for teens today.

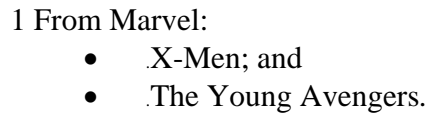


- The Authority;

- Green Lantern (sidekick character);

- The Invisibles;

- $\quad$ Stuck Rubber Baby; and

- Wonder Woman.

3 From other publishers:

- Charm School - SLG Publishing;

- $\quad$ El Hazard: Magnificent World (original OVA series) -VIZ Media LLC;

- $\quad$ Love and Rockets - Fantagraphics Books;

- Strangers in Paradise: High School - Abstract Studio;

- Fun Home: A Family Tragicomic - Houghton Mifflin; and

- Tough Love: High School Confidential - Manic D Press.

4 Additional resources can be found at:

- www.ncac.org/graphicnovels

- www.ala.org/ala/acrl/acrlpubs/crlnews/backissues2005/february05/comicbooks.htm www.ala.org/ala/yalsa/GraphicNovelResources.pdf

\section{References}

Advocate (2005), "Young love?", Advocate, No. 939, p. 28.

Applegate, D. (1994), Coming out in the Comic Strips, Bull Moose Publishing, Atlanta, GA.

Associated Press (2006), "As more graphic novels appear in libraries, so do challenges", available at: www.firstamendmentcenter.org/news.aspx?id1/417805 (accessed December 1, 2006).

Berkeley Public Library (2005), "GLBTQQ fiction: Gay, lesbian, bisexual, transgender, queer or questioning”, available at: http://berkeleypubliclibrary.org/teen/gay.html (accessed November 17, 2006).

Brenner, R. (2005), "No flying no tights", available at: www.noflyingnotights.com/index.html (accessed November 7 , 2006).

Bussert, L. (2005), "Comic books and graphic novels: digital resources for an evolving form of art and literature", College \& Research Libraries News, Vol. 66 No. 2, available at: www.ala.org/ala/acrl/acrlpubs/crlnews/backissues2005/february05/comicbooks.htm. (accessed December 1, 2006).

Dobnik, V. (2002), “August 14, 2002 - last update, comic book hero fights gay-bashing”, PlanetOut.com, available at: www.planetout.com/news/article.html?date1/42002/08/14/4 (accessed November 7, 2006).

Editor \& Publisher (1997), "Gay teen gets some reaction”, Vol. 130 No. 34, p. 39.

Ferber, L. (2002), "Shining a lantern on hate crimes", Advocate, September 17, pp. 61-2.

Giltz, M. (2003), "X woman", Advocate, No. 888, pp. 54-5.

Green, H. (2003), “These are not your father's comics”, Business Week Online, October 9, available at: www.businessweek.com/bwdaily/dnflash/oct2003/nf2003109_3603_db035.htm (accessed January 31, 2007).

Lavin, M. (2001a), "Comic books and censorship", available at: http://ublib.buffalo.edu/lml/comics/pages/censorship.html (accessed November 7, 2006).

Lavin, M. (2001b), "Selecting age-appropriate materials", available at: http://ublib.buffalo.edu/lml/comics/pages/age-approp.html (accessed November 7, 2006).

National Coalition against Censorship, American Library Association and Comic Book Legal Defense Fund (2006), "Graphic novels: suggestions for librarians", available at: www.ncac.org/graphicnovels (accessed January 31, 2007).

Newsarama.com (2005), "September market shares: based on actual sales for comics, magazines, and GNs invoiced in September 2005", available at: www.newsarama.com/marketreport/sept05sales.html (accessed November 30, 2006)

Nyberg, A.K. (1998), Seal of Approval: The History of the Comics Code, University Press of Mississippi, Jackson, MO.

PlanetOut.com (2005), "Not just 'Invisible”, available at: www.planetout.com/entertainment/comics/superheroes/jiminez.html (accessed November 7, 2005).

Provenzano, J. (n.d.), "Queer superheroes: a brief history", PlanetOut.com, available at: www.planetout.com/entertainment/comics/superheroes/comics.html (accessed November 7, 2006).

Raiteri, S. (2002), "Collection development: graphic novel collection development”, available at: www.ala.org/ala/yalsa/teenreading/trw/trw2002/collectiondevelopment.htm (accessed November 30, 2006).

Robbins, T. (1999), From Girls to Grrrlz: A History of Women's Comics from Teens to Zines, Chronicle Books, San Francisco, CA.

Theophano, T. (2002), "Comic strips and cartoons”, GLBTQq: An Encyclopaedia of Gay, Lesbian, Bisexual, 
Transgender and Queer Culture, available at:

www.GLBTQq.com/arts/comic_strips_cartoons.html (accessed November 7, 2006).

Twiddy, D. (2006), "Graphic novels draw criticism at libraries", available at:

http://timesunion.com/AspStories/story.asp?storyID1/4546037\&category1/4ARTS\&newsdate1/412/19/2006 (accessed January 31, 2007).

Williams, J. (1994), “Comics: a tool of subversion?", Journal of Criminal Justice and Popular Culture, Vol. 2 No. 6, pp. 129-46.

Young Adult Library Services Association (n.d.), "Great graphic novels for teens", available at: www.ala.org/ala/yalsa/booklistsawards/greatgraphicnovelsforteens/gn.htm (accessed December 1, 2006). 